\title{
PENGGUNAAN SKALA BRADEN TERBUKTI EFEKTIF DALAM MEMPREDIKSI KEJADIAN LUKA TEKAN
}

\author{
Era Dorihi Kale ${ }^{1 *}$, Elly Nurachmah ${ }^{2}$, Hening Pujasari $^{2}$ \\ 1. Jurusan Keperawatan, Politeknik Kesehatan Kemenkes Kupang, Kupang 85361, Indonesia \\ 2. Fakultas Ilmu Keperawatan, Universitas Indonesia, Depok 16424, Indonesia \\ *E-mail: fromerawithlove@yahoo.com
}

\begin{abstract}
Abstrak
Luka tekan merupakan luka karena tekanan yang berlangsung lama pada kulit dan jaringan yang dapat berakibat pada kondisi yang lebih serius. Luka tekan dapat dideteksi dengan menggunakan skala Braden. Penelitian ini bertujuan mengidentifikasi keefektifan menggunakan skala Braden dalam memprediksi kejadian luka tekan pada pasien yang dirawat di ruang perawatan bedah dan penyakit dalam, sebuah RSU di Kota Kupang. Penelitian ini merupakan penelitian kuantitatif dengan metode prospektif, yang melibatkan 28 pasien yang dipilih dengan teknik consecutive sampling. Hasil penelitian menunjukan bahwa skala Braden mempunyai validitas prediksi yang baik dengan nilai sensitifitas 88,2\% dan spesifitas $72,7 \%$. Hasil ini menunjukkan bahwa skala Braden efektif dalam memprediksi kejadian luka tekan. Oleh karena itu, skala Braden disarankan untuk digunakan sebagai alat skrining terhadap risiko terjadinya luka tekan terutama pada pasien yang mengalami perawatan yang lama.
\end{abstract}

Kata kunci: luka tekan, ruang rawat pasien medikal-bedah, skala Braden

\begin{abstract}
The Use of Braden Scale Proven Effective in Predicting the Incident of Pressure Ulcer. Ulcer pressure is a wound which occurs due to long pressure on skin and tissues resulting on more seriously condition. Pressure ulcer is preventable through early detection with Braden scale. This study aims to identify the effectiveness of Braden scale in predicting incident of pressure ulcer of patients in Medical-Surgical Ward at a General Hospital in Kupang. This prospective study involved in 28 subjects selected by consecutive sampling method. The result showed that Braden scale has validity in prediction with $88.2 \%$ sensitivity and $27.2 \%$ specificity. Braden scale is effective in predicting pressure ulcer and recommended to use as a screening tool to predict the incident of pressure ulcer.
\end{abstract}

Keywords: Braden Scale, medical-surgical war, pressure ulcer

\section{Pendahuluan}

Luka tekan adalah suatu lesi iskemik pada kulit dan jaringan di bawahnya yang disebabkan oleh adanya tekanan yang merusak aliran darah dan limfe. Keadaan iskemia ini menyebabkan nekrosis jaringan dan akan menimbulkan luka. Luka tekan ini bisa terjadi pada pasien yang berada dalam suatu posisi dalam jangka waktu lama baik posisi duduk maupun berbaring (Porth, 2005 dalam LeMone \& Burke, 2008). Di Indonesia, kejadian luka tekan pada pasien yang dirawat di rumah sakit mencapai 33\% (Suriadi, et al., 2007).
Kejadian luka tekan ini akan menimbulkan komplikasi serius pada pasien, misalnya sepsis dan kematian (Ayello, 2003). Jika sudah terjadi luka tekan maka penyembuhannya akan sulit dan memerlukan biaya yang tinggi, juga menyebabkan memanjangnya waktu rawat di rumah sakit, bahkan meningkatkan mortalitas (Ignatavicius \& Workman, 2006; \& Linton, Matteson, \& Maebius, 2004). Untuk itu penting bagi perawat melakukan berbagai upaya pencegahan terjadinya luka tekan pada pasien dengan cara mendeteksi secara dini faktor-faktor risiko terjadinya luka tekan. Untuk memfasilitasi pengkajian terhadap risiko terjadinya luka tekan pada pasien, maka 
Braden dan Bergstrom (1984) dalam Bergstrom, Demuth, dan Braden (1988) telah mengembangkan suatu alat yang disebut Braden scale (skala Braden).

Banyak penelitian yang telah dilakukan untuk menguji validitas dan reliabilitas dari alat ini. Hasil yang diperoleh bahwa skala Braden menunjukan validitas dan reliabilitas yang lebih tinggi bila dibandingkan dengan alat ukur yang lain yaitu Norton scale dan Waterlow scale (Ayello, 2003; Braden \& Mekleburst, 2005), namun pada pelaksanaan di tatanan pelayanan keperawatan saat ini belum menggunakan skala ini dan perawat cenderung untuk melakukan penilaian klinik (clinical judgement) dalam menilai risiko luka tekan pada pasien, sehingga sering terjadi kesalahan dalam penilaian risiko pasien.

RSU Kelas B Kupang merupakan RS pemerintah tipe B yang memiliki ruang perawatan penyakit bedah-dalam kelas II dan III berkapasitas total 108 tempat tidur. Angka kejadian luka tekan pada rumah sakit ini belum diketahui secara pasti. Berdasarkan wawancara dengan perawat yang bertugas di ruang perawatan bedah-dalam mengatakan bahwa luka tekan sering terjadi terutama pada pasien yang mengalami gangguan mobilisasi di ruangan ini. Rumah sakit ini juga belum pernah menggunakan skala Braden dalam mendeteksi kejadian risiko luka tekan pada pasien dan juga belum pernah dilakukan uji validitas prediksi terhadap skala Braden.

Merujuk kepada pendapat Suriadi, et al., (2008) bahwa validitas prediksi suatu skala pengkajian risiko dapat dipengaruhi oleh karakteristik suatu populasi, maka perlu mengevaluasi sejauh mana validitas prediksi alat tersebut pada populasi yang besangkutan sebelum alat itu digunakan. Dengan demikian dianggap perlu untuk melakukan penelitian tentang keefektifan skala Braden dalam mendeteksi kejadian luka tekan di ruang perawatan bedah-dalam RSU Kelas B Kupang.

\section{Metode}

Desain penelitian prospektif untuk mengidentifikasi keefektifan skala Braden dalam memprediksi kejadian luka tekan di ruang perawatan BedahDalam RSU Kelas B Kupang pada bulan AprilMei 2009. Kriteria inklusi: 1) Bersedia diteliti dengan menandatangani lembar persetujuan. 2) Mempunyai gangguan mobilisasi parsial atau penuh, yang ditentukan berdasarkan adanya diagnosis keperawatan gangguan mobilisasi fisik. Kriteria Eklusi: 1) Mempunyai riwayat luka tekan sebelumnya. 2) Pasien yang dirawat kurang dari 6 hari. Sampel diambil secara concecutive sampling dengan besar sampel 28.

Pengukuran risiko luka tekan dengan menggunakan skala Braden dengan uji validitas menggunakan Pearson dan uji reliabilitas menggunakan Alpha-Cronbach didapatkan semua item subskala valid $(\mathrm{r}>0,632)$. Uji reliabilitas didapatkan nilai r Alpha $(0,899)$. Analisis bivariat dengan menggunakan Khi kuadrat. Observasi harian kondisi kulit, tekanan darah dan suhu tubuh dilakukan oleh pengumpul data menggunakan lembar observasi. Pengumpul data pada penelitian ini sebanyak 4 orang, masingmasing ruangan 1 orang. Pengumpul data telah dilatih dalam mengobservasi kondisi kulit dan dilakukan uji persamaan persepsi, dengan hasil koefisien Kappa $(\mathrm{K}=0,71)$.

\section{Hasil}

Berdasarkan Tabel 1 dapat dilihat bahwa proporsi responden laki-laki dan perempuan berimbang (laki-laki dan perempuan 50\%). Jika dilihat dari diagnosis medik responden maka nampak bahwa $50 \%$ responden dirawat dengan diagnosis medik stroke, selebihnya dengan diagnosis pasca operasi, DM dan penyakit lainnya. Mayoritas responden (75\%) memiliki riwayat tidak merokok dan lebih dari sebagian responden menderita luka tekan $(60,7 \%)$.

Tabel 2 menunjukan rata-rata usia responden adalah 54,29 tahun dengan usia termuda berusia 15 tahun dan responden tertua 74 tahun. Ratarata IMT adalah $23,15 \mathrm{~kg} / \mathrm{m}^{2}$, sedangkan IMT terendah $16,40 \mathrm{~kg} / \mathrm{m}^{2}$ dan IMT tertinggi adalah $35,30 \mathrm{~kg} / \mathrm{m}^{2}$. Suhu tubuh responden memiliki rata-rata $36,73{ }^{\circ} \mathrm{C}$, sedangkan suhu terendah adalah $36,2^{\circ} \mathrm{C}$ dan suhu tertinggi adalah $38,50^{\circ} \mathrm{C}$. 
Tabel 1. Karakteristik Responden Berdasarkan Jenis Kelamin, Diagnosis Medik, Riwayat Merokok dan Kejadian Luka Tekan

\begin{tabular}{llcr}
\hline Variabel & & Jumlah & Persentase (\%) \\
\hline Jenis Kelamin & Laki-laki & 14 & 50 \\
& Perempuan & 14 & 50 \\
Diagnosis Medik & Stroke & 14 & 50 \\
& Pasca operasi & 3 & 10,71 \\
& DM (Diabetes Mellitus) & 2 & 7,14 \\
\multirow{2}{*}{ Riwayat Merokok } & lainnya & 9 & 32,14 \\
& Merokok & 7 & 25 \\
Kejadian Luka Tekan & Tidak merokok & 21 & 75 \\
& Ada luka & 17 & 60,7 \\
\hline
\end{tabular}

Tabel 2. Karakteristik Berdasarkan Usia, IMT, Suhu Tubuh, Tekanan Darah, dan Skor Skala Braden

\begin{tabular}{lrrrr}
\hline \multicolumn{1}{c}{ Variabel } & Mean & \multicolumn{1}{c}{ SD } & 95\% CI & Minimal-maksimal \\
\hline Usia & 54,29 & 17,20 & $47,62-60,95$ & $15-74$ \\
IMT (Indeks Masa Tubuh) & 23,15 & 5,0 & $21,32-25,21$ & $16,40-35,30$ \\
Suhu Tubuh & 36,73 & 0,57 & $36,51-36,95$ & $36,20-38,50$ \\
Tekanan Darah Sistolik & 134 & 23,84 & $124,75-143,27$ & $91-175$ \\
Tekanan Darah Diastolik & 83,28 & 11,86 & $78,68-87,88$ & $59-100$ \\
Skor Skala Braden & 13,67 & 3,96 & $12,14-15,21$ & $6,00-22,00$ \\
\hline
\end{tabular}

Tabel 3. Hasil Uji Homogenitas Variabel Konfonding

\begin{tabular}{|c|c|c|c|c|c|c|}
\hline \multirow{3}{*}{ Variabel } & \multicolumn{4}{|c|}{ Kejadian luka } & \multirow{3}{*}{$\begin{array}{c}\text { Total } \\
\mathbf{n}\end{array}$} & \multirow{3}{*}{$\mathbf{p}$} \\
\hline & \multicolumn{2}{|c|}{ Ada luka } & \multicolumn{2}{|c|}{ Tidak ada luka } & & \\
\hline & $\mathbf{n}$ & $\%$ & $\mathbf{N}$ & $\%$ & & \\
\hline \multicolumn{7}{|l|}{ Usia } \\
\hline$\geq 70$ & 3 & 10,7 & 4 & 14,3 & 7 & 0,381 \\
\hline$\overline{<} 70$ & 14 & 50 & 7 & 25 & 11 & \\
\hline \multicolumn{7}{|l|}{ IMT } \\
\hline Kurang & 5 & 17,9 & 0 & 0 & 5 & 0,565 \\
\hline Normal & 9 & 32,1 & 6 & 21,4 & 15 & \\
\hline Lebih & 2 & 7,1 & 3 & 10,7 & 5 & \\
\hline Obesitas & 1 & 3,6 & 2 & 7,1 & 3 & \\
\hline \multicolumn{7}{|l|}{ Riwayat merokok } \\
\hline Merokok & 4 & 14,3 & 3 & 10,7 & 7 & 1,000 \\
\hline Tidak merokok & 13 & 46,4 & 8 & 28,6 & 21 & \\
\hline \multicolumn{7}{|l|}{ Diagnosa Medik } \\
\hline Vaskular perifer & 3 & 10,7 & 0 & 0 & 3 & \\
\hline Bukan vaskular perifer & 14 & 50 & 11 & 39,3 & 25 & 0,258 \\
\hline \multicolumn{7}{|l|}{ Suhu Tubuh } \\
\hline$<37,4{ }^{\circ} \mathrm{C}$ & 14 & 50 & 11 & 39,3 & 25 & 0,258 \\
\hline$\geq 37,4^{\circ} \mathrm{C}$ & 3 & 10,7 & 0 & 0 & 3 & \\
\hline \multicolumn{7}{|l|}{ TD sistolik (mmHg) } \\
\hline$<100$ & 2 & 7,1 & 0 & 0 & 2 & 0,505 \\
\hline$\geq 100$ & 15 & 53,6 & 11 & 39,3 & 26 & \\
\hline \multicolumn{7}{|l|}{ TD diastolik (mmHg) } \\
\hline$<60$ & 1 & 3,6 & 0 & 0 & 1 & 1,000 \\
\hline$\geq 60$ & 16 & 57,1 & 11 & 39,3 & 27 & \\
\hline
\end{tabular}


Tabel 4. Validitas Prediksi Skala Braden di Ruang Perawatan Penyakit Bedah-Dalam

\begin{tabular}{ccccc}
\hline Cut of Point & $\begin{array}{c}\text { Sensitifitas } \\
(\mathbf{\%})\end{array}$ & $\begin{array}{c}\text { Spesifitas } \\
(\mathbf{\%})\end{array}$ & $\begin{array}{c}\text { FN } \\
(\mathbf{\%})\end{array}$ & $\begin{array}{c}\text { FP } \\
(\mathbf{\%})\end{array}$ \\
\hline 11 & 35,3 & 90,9 & 64,7 & 9,1 \\
12 & 41,2 & 81,8 & 58,8 & 18,2 \\
13 & 47,1 & 81,8 & 52,9 & 18,2 \\
14 & 82,4 & 72,7 & 17,6 & 27,3 \\
15 & 88,2 & 72,7 & 11,8 & 27,3 \\
16 & 94,1 & 54,5 & 5,9 & 45,5 \\
17 & 100 & 54,5 & 0 & 45,5 \\
18 & 100 & 9,1 & 0 & 90,9 \\
\hline
\end{tabular}

Pada pengukuran tekanan darah dijumpai ratarata tekanan darah sistolik adalah $134 \mathrm{mmHg}$, tekanan darah sistolik terendah adalah $91 \mathrm{mmHg}$ dan tekanan darah sistolik tertinggi adalah 175 mmHg. Dari Tabel 2 juga terlihat bahwa ratarata tekanan darah diastolik responden 83,28 mmHg. Rata-rata skor skala Braden responden adalah 13,67 dengan skor terendah adalah 6 dan skor tertinggi adalah 22 .

Hasil uji statistik menunjukkan bahwa tidak ada perbedaan yang bermakna antara usia, IMT, riwayat merokok, diagnosis medik, suhu tubuh dan tekanan darah pada kelompok yang mengalami luka dengan usia pada kelompok yang tidak terjadi luka $(p>0,05)$

Berdasarkan Tabel 4 dapat dilihat bahwa dari skor 14 keatas didapatkan sensitifitas $82,4 \%$ $100 \%$ dengan spesifitas pada skor 15 ke bawah berkisar 72,7\%-81,8\%. Dari hasil tersebut diambil titik keseimbangan paling baik pada skor 15 dimana nilai sensitifitas dan spesifitas tertinggi dengan nilai FP dan FN terendah. Dengan demikian pada populasi ini skor 15 dipakai sebagai cut of point, dimana nilai sensitifitas $88,2 \%$, spesifitas $72,7 \%$, FN $11,8 \%$ dan FP 27,3\%.

Berdasarkan hasil perhitungan dengan memasukan nilai sensitifitas dan nilai false positive ke dalam program komputer, maka didapatkan luas area di bawah kurva pada penelitian ini adalah 0,880. Luas area di bawah kurva ini telah diklasifikasikan berdasarkan kemampuan prediksi suatu alat, yaitu: sempurna $=0,9-1$; Baik $=0,8-00,9$; cukup $=0,7-0,8$; kurang $=0,6-$ 0,7 dan gagal $=0,5-0,6$. Dengan memiliki luas area di bawah kurva sebesar 0.880, maka skala Braden memiliki nilai prediksi yang baik terhadap kejadian luka tekan pada pasien ruang perawatan bedah-dalam RSU Prof. Dr. W.Z. Yohannes Kupang.

\section{Pembahasan}

Kejadian Luka Tekan. Berdasarkan hasil penelitian, angka kejadian luka tekan pada pasien yang imobilisasi di ruang perawatan bedah dalam RSU B Kupang pada bulan April dan Mei 2009 mencapai 60.7\%. Angka ini cukup tinggi jika dibandingkan dengan pendapat Porth tahun 2005 (dalam LeMone \& Bukre, 2008) yang mengatakan bahwa insiden luka tekan di rumah sakit mencapai $8 \%$ dan insiden luka tekan di unit perawatan jangka panjang berkisar 2,4$23 \%$, sedangkan di Pontianak, kejadian luka tekan pada pasien yang dirawat di ICU mencapai 33\% (Suriadi, et al., 2007).

Peneliti berpendapat bahwa angka kejadian luka tekan bisa berbeda, tergantung pada karakteristik 
populasi tersebut dan juga penataan ruang perawatan pasien. Kejadian luka tekan akan meningkat pada ruang perawatan jangka panjang dan juga ICU dimana pasien yang dirawat memiliki hambatan dalam melakukan mobilisasi dan tingkat ketergantungan yang tinggi dalam melakukan aktifitas.

Validitas Prediksi Skala Braden. Validitas Prediksi skala Braden ditentukan oleh nilai Spesifitas, Sensitifitas, False Positive (FP) dan False Negative (FN). Hasil penelitian manunjukan bahwa, bila dilihat dari skor 14 keatas maka akan didapatkan sensitifitas skala Braden berkisar dari 82,4\%-100\% dengan spesifitas pada skor 15 ke bawah berkisar 72,7\%-81,8\%. Dengan menggunakan cut of point 15, maka validitas prediksi skala Braden adalah sensitifitas $88,2 \%$, spesifitas $72,7 \%$, FP $27,3 \%$ dan FN 11,8\% dan luas area di bawah kurva ROC adalah 0,880 .

Hasil penelitian ini didukung oleh Ayello (2003) dalam review literaturnya yang diperoleh dari 14 data dasar untuk memprediksi kejadian luka tekan menggunakan skala Braden pada pasien lanjut usia di 14 unit perawatan akut dan perawatan di rumah. Hasilnya menunjukan bahwa kemampuan skala Braden untuk memprediksi terjadinya luka tekan cukup baik, dengan nilai sensitifitas skor 16 ke bawah berkisar dari 83\%-100\% dan spesifitas pada skor 17 kebawah berkisar dari $64 \%-90 \%$, tergantung dari cut of point yang digunakan. Kwong, et al., (2005) menganjurkan untuk menggunakan cut of point 16 untuk skala Braden yang sudah di modifikasi.

Walaupun demikian, peneliti merasa perlu untuk diperhatikan adanya overprediction ataupun underprediction yang ditimbulkan dengan penggunaan skala Braden. Dengan Spesifitas sebesar 72,7\% akan menimbulkan overprediction sebesar $27,3 \%$, yang berarti dari 100 orang yang dikatakan berisiko terjadi luka tekan, 27,3 orang tidak akan mengalami luka tekan. Kondisi overprediction ini akan menyebabkan pengeluaran biaya dan tenaga yang tidak perlu untuk mencegah terjadinya luka tekan pada orang yang memerlukan tindakan tersebut; sedangkan underprediction ditentukan oleh nilai FN, dimana pada penelitian ini ditemukan sebesar $11,8 \%$ yang berarti dari 100 orang yang dikatakan tidak berisiko terjadi luka tekan, terdapat 11,8 orang yang akan mengalami luka tekan. Hal ini menyebabkan adaya pasien yang berisiko terjadi luka tekan tetapi tidak mendapat tindakan pencegahan yang dibutuhkan. Dengan adanya underprediction ini diharapkan bagi perawat melakukan pemeriksaan kulit secara teratur walaupun pada pasien yang tidak berisiko terjadi luka tekan untuk mendeteksi adanya kerusakan kulit tahap awal, sehingga kegagalan mendeteksi risiko pada $11,8 \%$ pasien dapat dideteksi untuk diberikan tindakan yang sesuai.

\section{Kesimpulan}

Hasil penelitian dapat disimpulkan bahwa kejadian luka tekan di ruang perawatan bedah-dalam cukup tinggi, skala Braden efektif dalam memprediksi kejadian luka tekan dan secara statistik tidak ditemukan adanya pengaruh variabel perancu terhadap kejadian luka tekan di ruang perawatan Bedah-Dalam RSU B Kupang.

Disarankan kepada bagian keperawatan RSU B Kupang untuk mengujicobakan terlebih dahulu skala Braden pada beberapa pasien di ruang perawatan lain melalui Evidence Based Practice (EBP). Setelah terbukti efektif, maka skala ini dijadikan Standar Prosedur Operational (SPO) perawatan pasien imobilisasi. Sebelum diimplementasikan menjadi SPO terlebih dahulu diberikan pelatihan kepada perawat yang akan menggunakannya. Bagi institusi pendidikan keperawatan juga perlu memasukan materi tentang penggunaan skala Braden kedalam kurikulum pembelajaran. Untuk penelitian selanjutnya disarankan untuk melakukan penelitian lanjutan dengan sampel yang lebih besar sehingga dapat diidentifikasi adanya pengaruh variabel perancu dengan alat pengumpul data yang sudah terstandarisasi. Karena adanya perbedaan karakteristik masing-masing populasi, maka disarankan untuk dilakukan uji validitas prediksi skala ini sebelum digunakan pada populasi yang berbeda. 
Rencana tindak lanjut dalam mengaplikasikan hasil penelitian ini pada tatanan praktek keperawatan dimulai dengan menyampaikan hasil penelitian ini kepada pembuat kebijakan di rumah sakit untuk dapat memasukan penggunaan skala Braden ke dalam protap perawatan pasien imobilisasi. Kemudian perawat ruangan diberi pelatihan tentang penggunaan skala Braden dan protap perawatan pasien imobilisasi bedasarkan tingkat risiko masing-masing pasien. Setelah 3 bulan pelaksanaan maka dilakukan evaluasi terhadap keberhasilan dan kendala-kendala yang dihadapi dalam menerapkan skala Braden ini dan dilakukan perbaikan. Kemampuan menggunakan skala Braden seyogyanya ditetapkan dalam kurikulum khususnya terkait pada askep medikal bedah agar setiap lulusan memilki kemampuan dalam menggunakan skala Braden untuk mencegah terjadinya luka tekan pada pasien. Penelitian ini menemukan bahwa skala Braden efektif dalam memprediksi kejadian luka tekan di ruang perawatan bedah dalam RSU B Kupang dan dapat dijadikan data dasar bagi penelitian selanjutnya tentang pencegahan luka tekan melalui penggunaan skala deteksi risiko $(\mathrm{JH}$, AW)

\section{Ucapan Terima Kasih}

Terima kasih kepada Kemenkes RI yang telah memberikan bantuan dana dalam pelaksanaan penelitian ini.

\section{Referensi}

Ayello, E.A. (2003). Predicting pressure ulcer risk. Diambil dari https://www.ncbi.nlm.nih.gov/ pubmed/12736933. Tanggal 11 Pebruari 2009.

Bergstrom, N., Demuth, PJ., \& Braden, BJ. (1988). A clinical trial of the braden scale for predicting pressure sore risk. Diambil dari http://www.ncbi.nlm.nih.gov/pubmed/3554150 tanggal 8 Pebruari 2009.

Braden, B.J., \& Maklebust, J. (2005). Preventing Pressure ulcer with Braden scale. Diambil dari http://www.healthsystem.virginia.edu/internet/ pnso/ nurseeducation/Slide-16-The-BradenScale.pdf tanggal 7 Pebruari 2009.

Ignatavicius, D \& Workman. (2006). Medical Surgical Nursing; Critical Thinking for Collaborative Care. $5^{\text {th }}$ edition. Philadelphia: W.B. Sounders Company.

Kwong, E., Pang, S., Wong, T., Shao-ling, X. \& Li-un, T. (2005). Predicting Pressure Ulcer Risk with the Modified Braden, Braden and Norton Scales in Acute Care Hospitals in Mainland China. Applied Nurs Res, 18(2), 8122.

LeMone, P. \& Burke, K. (2008). Medical Surgical Nursing: Critical Thinking in Client Care. 4th edition. USA: Pearson prentice hall.

Linton, A.D., Matteson, M.A., \& Maebius, N.K. (2004). Introductory Nursing Care of Adults. 2nd Edition. Philadelphia: W.B. Saunders Company.

Suriadi, Sanada, H., Sugama, J., Kitagawa, A., Thigpen, B., Kinosita, S., \& Murayama, S. (2007). Risk factors in the development of pressure ulcers in an Intensive Care Unit in Pontianak, Indonesia. International Wound Journal, 4 (3), 208-215.

Suriadi, Sanada, H., Sugama, J., Thigpen,B., \& Subuh, M. (2008). Development of a new risk assessment scale for predicting pressure ulcer in an Intensive Care Unit. Journal Compilation British Association of Critical Care Nurses, 13(1), 34-43. 